\title{
Dynamic changes in peripheral blood lymphocyte subset counts and functions in patients with diffuse large B cell lymphoma during chemotherapy
}

Hongyan Hou ${ }^{1}$, Ying Luo ${ }^{1}$, Guoxing Tang ${ }^{1}$, Bo Zhang ${ }^{1}$, Renren Ouyang ${ }^{1}$, Ting Wang ${ }^{1}$, Min Huang ${ }^{1}$, Shiji Wu ${ }^{1 *}$, Dengju $\mathrm{Li}^{2^{*}}$ and Feng Wang ${ }^{*^{*}}$ (D)

\begin{abstract}
Background: This study aimed to analyze the lymphocyte subsets, their activities and their dynamic changes during immunochemotherapy in patients newly diagnosed with diffuse large B cell lymphoma (DLBCL).

Methods: Patients with DLBCL $(n=33)$ were included in the present study. Their peripheral lymphocyte subsets, phenotypes and functions were detected using flow cytometry. The dynamic results of lymphocyte activities were available for 18 patients.

Results: Compared with healthy controls ( $\mathrm{HCS}$ ), the counts of $\mathrm{CD}^{+}, \mathrm{CD}^{+}$, and $\mathrm{CD} 8^{+} \mathrm{T}$ cells as well as those NK cells decreased in patients newly diagnosed with $D L B C L$, mainly attributed to patients with high risk of prognosis assessed by International Prognostic Index (IPI) score. Lymphocyte counts didn't present significant difference between high risk (IPI scores 3-5) and low risk patients (IPI scores $0-2$ ), but $C D 4^{+} T$ cells and $C D 8^{+} T$ cells expressed higher levels of CD28 and HLA-DR, respectively, in patients with IPI score ranging from 3 to 5 . Patients at high risk harbored higher percentage of regulatory T cells (Tregs), and their $\mathrm{CD}^{+}$and $\mathrm{CD} 8^{+} \mathrm{T}$ cells produced lower levels of IFN- $\gamma$, reflecting an impaired cellular immune response. The dynamic changes of lymphocyte numbers and functions during treatment were further investigated. Total counts of $\mathrm{CD}^{+}, \mathrm{CD}^{+}, \mathrm{CD}^{+} \mathrm{T}$ and $\mathrm{NK}$ cells progressively decreased because of the cytotoxicity of chemotherapy and then gradually recovered after six cycles treatment (rituximab combined with cyclophosphamide, doxorubicin, vincristine and prednisone, $\mathrm{R}-\mathrm{CHOP}$ ). The functions of $\mathrm{CD} 4^{+}$and $\mathrm{CD} 8^{+} \mathrm{T}$ cells recovered by the end of two cycles R-CHOP treatment, although NK cell function was not significantly affected throughout treatment. These results suggest that the counts and functions of lymphocytes are significantly decreased in patients with $\mathrm{DLBCL}$, particularly those of $\mathrm{CD} 4^{+}$and $\mathrm{CD} 8^{+} \mathrm{T}$ cells.
\end{abstract}

Conclusions: The absolute counts and functions of $\mathrm{CD} 4^{+}, \mathrm{CD} 8^{+} \mathrm{T}$ cells, which were significantly lower in patients with $\mathrm{DLBCL}$, gradually recovered after effective treatment. Therefore, combined detection of T cell counts and

\footnotetext{
*Correspondence: wilson547@163.com; lidengju@163.com;

fengwang@tjh.tjmu.edu.cn

${ }^{1}$ Department of Laboratory Medicine, Tongji Hospital, Tongji Medical

College, Huazhong University of Science and Technology, Jiefang Road

1095, Wuhan 430030, China

${ }^{2}$ Department of Hematology, Tongji Hospital, Tongji Medical College,

Huazhong University of Science and Technology, Wuhan, China
}

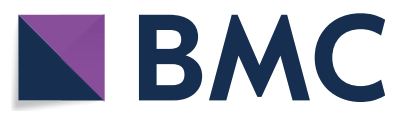

(c) The Author(s) 2021. This article is licensed under a Creative Commons Attribution 4.0 International License, which permits use, sharing, adaptation, distribution and reproduction in any medium or format, as long as you give appropriate credit to the original author(s) and the source, provide a link to the Creative Commons licence, and indicate if changes were made. The images or other third party material in this article are included in the article's Creative Commons licence, unless indicated otherwise in a credit line to the material. If material is not included in the article's Creative Commons licence and your intended use is not permitted by statutory regulation or exceeds the permitted use, you will need to obtain permission directly from the copyright holder. To view a copy of this licence, visit http://creativeco mmons.org/licenses/by/4.0/. The Creative Commons Public Domain Dedication waiver (http://creativecommons.org/publicdomain/ zero/1.0/) applies to the data made available in this article, unless otherwise stated in a credit line to the data. 
functions are critically important for administering effective personalized immunotherapy as well as for identifying new prognostic markers or DLBCL.

Keywords: Diffuse large B cell lymphoma, Lymphocyte subsets, CD4 ${ }^{+} \mathrm{T}$ cells, CD8 ${ }^{+} \mathrm{T}$ cells, NK cells

\section{Background}

Diffuse large B-cell lymphoma (DLBCL) is the most common subtype of non-Hodgkin's lymphoma (NHL), accounting for approximately $40 \%$ of lymphoid malignancies [1]. DLBCL is clinically, pathologically, and molecularly heterogeneous; and the responses of patients to therapy and their survival times are highly variable. The International Prognostic Index (IPI) is widely used to identify patients at high risk of death [2]. However, combined treatment with the anti-CD20 monoclonal antibody rituximab (R), cyclophosphamide, doxorubicin, vincristine and prednisone (CHOP) dramatically improves the treatment outcomes of patients with DLBCL regardless of IPI score and pathological type $[3,4]$. Moreover, one-third of patients will be refractory or develop a relapse after R-CHOP treatment [5], indicating that potential risk factors must be identified to develop more effective therapies.

The host's immune system exerts critical anticancer effects, and its dysfunction contributes to pathogenesis and disease progression [6,7]. Lymphocytopenia serves as a marker of poor prognostic during the initial stages of NHL, HL and relapsed DLBCL [8]. Early recovery of lymphocytes after autologous and allogeneic stem cell transplantation serves as a significant predictor of lymphoma control and a patient's survival. The absolute lymphocyte counts and subsets reflected systemic immunity and predict the prognosis of patients with DLBCL. Furthermore, the success of cancer immunotherapy shows the importance of analysis of the host's systematic immune response to assess the outcome of DLBCL $[9,10]$.

The types and numbers of specific $T$ cell subsets that infiltrate B-cell lymphomas are associated with relapse and survival [11]. $\mathrm{CD} 4^{+} \mathrm{T}$ cells are generally considered beneficial and lower numbers of these cells are associated with a poor response to treatment and unfavorable prognosis of patients with DLBCL [11-13]. In contrast, elevated numbers of infiltrating cytotoxicity $\mathrm{CD} 8^{+} \mathrm{T}$ cells are associated with good outcomes of patients with B cell lymphomas [14]. Regulatory $\mathrm{T}$ cells (Tregs) suppress the functions of other immune cells and may correlate with prognostic factors of high risk [15]. Furthermore, natural killer (NK) cells play a critical role in innate immune surveillance, and a deficiency in NK cells is a potential marker of the severity of disease [8]. Although previous studies have reported the relationships between the lymphocyte numbers and lymphomas, further investigations are required to evaluate immune status through determining the numbers and functions of peripheral-blood lymphocytes.

Here we prospectively determined the numbers, phenotypes, and functions of peripheral $\mathrm{CD}^{+} \mathrm{T}, \mathrm{CD} 8^{+} \mathrm{T}$ cells, B cells, and NK cells upon diagnosis according to IPI scores. We next determined the dynamic changes in lymphocyte subsets and activities in response to treatment with R-CHOP. Further evaluation of the immune responses of patients with DLBCL is critically important for efforts to identify new prognostic markers and to develop individualized immunotherapies.

\section{Methods \\ Patients}

This was a retrospective study, approved by the ethical committee of Tongji hospital, Tongji Medical College, Huazhong University of Science and Technology. From January 2018 to October 2019, 33 newly diagnostic DLBCL patients were recruited, including 13 females and 20 males. 18 patients were classified as stage I/II and 15 patients were classified as stage III/IV according to the Ann Arbor classification system. In the patients receiving treatment, each cycle was period was 20 days and 18 patients accompanied at least six cycles of R-CHOP treatment. In addition, 33 age and sex matched healthy controls (HCs) were also recruited and determined by interview and physical examination. The exclusive criteria include HIV and HCV positive. Peripheral blood for detection of lymphocyte subsets, phenotype and function was collected at each of following time-points: T0, newly diagnosis; T1, after the accomplishment of two cycles' treatment; T2, after four cycles' treatment; T3, after six cycles' treatment. All of the subjects gave written informed consent.

\section{TBNK lymphocyte counting}

The percentages and absolute numbers of $\mathrm{CD} 4^{+} \mathrm{T}$ cells, $\mathrm{CD}^{+} \mathrm{T}$ cells, B cells, and NK cells were determined using TruCOUNT tubes and BD Multitest 6-color TBNK Reagent Kit (BD Biosciences) according to the manufacturer's instructions. In brief, $50 \mu \mathrm{L}$ of whole blood was labeled with 6-color TBNK Ab cocktail for $15 \mathrm{~min}$ in room temperature. After adding $450 \mu \mathrm{L}$ of FACS lysing solution, samples were analyzed with FACSCanto 
flow cytometer using FACSCanto clinical software (BD Biosciences).

\section{Lymphocyte phenotype analysis}

The following monoclonal antibodies and regents were purchased from BD Biosciences and added to $100 \mu \mathrm{l}$ of whole blood. The panel of antibodies in tube 1 were antiCD45-PerCP $(652,803)$, anti-CD3-APC-H7 $(663,490)$, anti-CD4-V450 (560,345), anti-CD8-PE/Cy7 $(335,822)$, anti-CD28-PE $(340,046)$, anti-HLA-DR-APC $(652,809)$. The panel of antibodies in tube 2 were anti-CD45-PerCP $(652,803)$, anti-CD3-APC-H7 (663,490), anti-CD4V450 (560,345), antiCD45RA-FITC $(662,840)$, and antiCD45RO-PE $(663,530)$, anti-CD25-APC $(662,525)$ and anti-CD127-PE/Cy $(560,822)$. The phenotype of NK cells were detected using anti-CD45-PerCP $(652,803)$, antiCD3-TITC $(349,201)$, anti-CD56-PE/Cy7 $(652,825)$ and CD69-PE $(557,050)$. Isotype controls with irrelevant specificities were included as negative controls. All of these cell suspensions were incubated for $20 \mathrm{~min}$ at room temperature. After lysing red blood cells with lysing solution $(349,202)$, the cells were washed and re-suspended in $200 \mu \mathrm{l}$ of PBS. The cells were then analyzed with FACSCanto flow cytometer.

\section{Lymphocyte function analysis}

The evaluation of lymphocyte function should be conducted before chemotherapy at each time point. PMA/ ionomycin-stimulated lymphocyte function assay was performed as described in our previous studies $[16,17]$. The procedures were described as follows: 1) $100 \mu \mathrm{l}$ of whole blood was diluted with $400 \mu \mathrm{l}$ of IMDM medium; 2) the diluted whole blood was stimulated with Leukocyte Activation Cocktail (Becton Dickinson GolgiPlug) for $4 \mathrm{~h}$; 3 ) the cells were stained with the following monoclonal antibodies anti-CD45-PerCP $(652,803)$, anti-CD3-TITC (349,201), anti-CD4-APC/H7 (341,115), anti-CD56-PE/ Cy7 $(652,825)$, and anti-CD8-PE $(340,046)$, followed by fixation and permeabilized $(554,722)$, and staining with intracellular anti-IFN- $\gamma$-APC antibody $(554,702)$. 4) the cells were analyzed with FACSCanto flow cytometer.

\section{Statistical analysis}

The results are presented as median \pm standard deviation (SD). The differences of markers among different groups were compared by analysis of variance (ANOVA). Statistical analyses were performed using GraphPad Prism version 6. Statistical significance was determined as $p<0.05$.

\section{Results}

The present study included 33 patients diagnosed with DLBCL, including 13 (39.4\%) females and 20 (60.6\%) males, median age 56 years $\left(25^{\text {th }}-75^{\text {th }}\right.$ quartiles, range 36.5-67.5 years). Patients included were classified with stages I/II $(\mathrm{n}=18,54.5 \%)$ and III/IV $(\mathrm{n}=15,45.5 \%)$ according to the Ann Arbor classification system. The IPI scores of 23 and 10 patients ranged from 0 to 2 and 3 to 5 , respectively. Patients' characteristics and laboratory test results of are shown in Table 1.

Analysis of lymphocyte subsets in peripheral blood revealed that decreased proportions of NK cells were present in patients with DLBCL at diagnosis compared with those of HCs, although there were no significant differences in the frequencies of $\mathrm{CD}^{+}, \mathrm{CD}^{+}$, and $\mathrm{CD} 8^{+} \mathrm{T}$ cells and $\mathrm{B}$ cells (Fig. 1A). Accordingly, the absolute numbers of $\mathrm{CD}^{+}, \mathrm{CD}^{+}, \mathrm{CD}^{+} \mathrm{T}$ cells and NK cells were significantly lower in patients with DLBCL compared with those of $\mathrm{HCs}$, although the numbers of $\mathrm{B}$ cells were similar (Fig. 1B). The templates used for the analysis of lymphocyte phenotypes in patients with DLBCL were shown in Additional file 1: Figure S1. The results show that the levels of the co-stimulatory molecule CD28 and the immune activation marker HLA-DR expressed by $\mathrm{CD}_{4}^{+} \mathrm{T}$ and $\mathrm{CD}^{+} \mathrm{T}$ cells were not significantly different (Fig. 1C). Decreased percentages of naïve $\mathrm{T}$ cells $\left(\mathrm{CD}^{+} /\right.$ $\mathrm{CD}^{2} 5 \mathrm{RA}^{+} / \mathrm{CD} 45 \mathrm{RO}^{-}$) and elevated percentages of memory $\mathrm{T}$ cells $\left(\mathrm{CD}^{+} / \mathrm{CD} 45 \mathrm{RA}^{-} / \mathrm{CD} 45 \mathrm{RO}^{+}\right)$were observed

Table 1 Baseline characteristics of patients

\begin{tabular}{ll}
\hline Characteristics & Values \\
\hline Patients & 33 \\
Median age, years (range) & $56(36.5-67.5)$ \\
Sex & \\
Female & $13(39.4 \%)$ \\
Male & $20(60.6 \%)$ \\
Ann Arbor stage & \\
I-II & $18(54.5 \%)$ \\
III-IV & $15(45.5 \%)$ \\
Laboratory results & \\
LDH (U/L) & $442.2 \pm 399.3$ \\
Neutrophiles $\left(\times 10^{9}\right.$ per L) & $3.933 \pm 2.077$ \\
Lymphocytes $\left(\times 10^{9}\right.$ per L) & $1.523 \pm 1.981$ \\
Hemoglobin $(g / L)$ & $110.7 \pm 28.93$ \\
Platelet $\left(\times 10^{9}\right.$ per L) & $185.2 \pm 108.3$ \\
IPI score & \\
$0-1$ & $11(33.3 \%)$ \\
2 & $12(36.4 \%)$ \\
3 & $6(18.2 \%)$ \\
$4-5$ & $4(12.1 \%)$ \\
\hline
\end{tabular}

Data are presented as mean \pm SD or numbers (\%) 

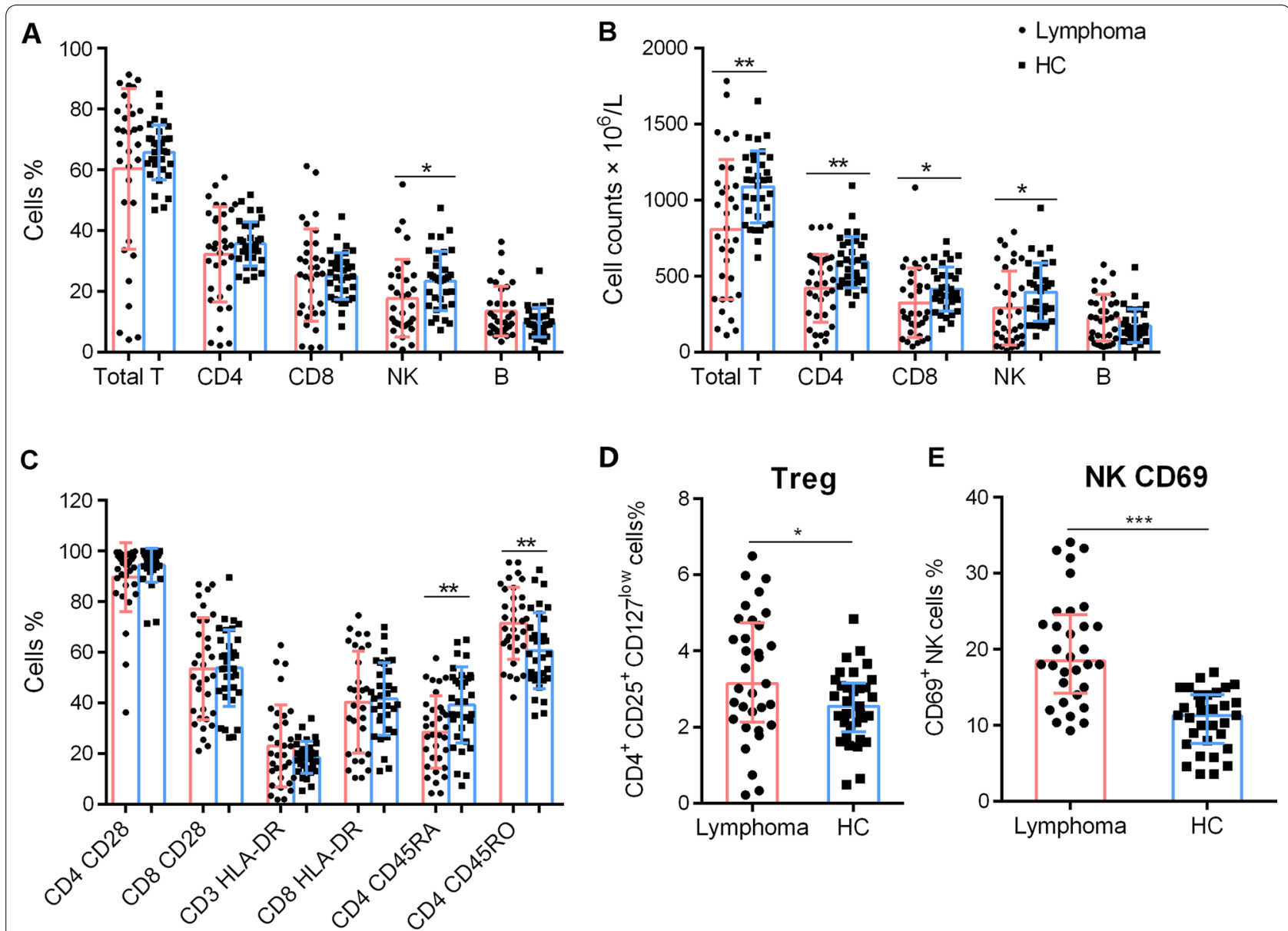

Fig. 1 The lymphocyte subsets and immunophenotypic characteristics. Circulating lymphocytes in patients newly diagnosed with DLBCL and healthy controls (HCs) were analyzed using flow cytometry. A, B The percentages and absolute numbers of T cells, B cells and NK cells in different groups are shown in bar graphs (mean \pm SD). $\mathbf{C}$ The expression of CD28 on CD4 ${ }^{+}$and $\mathrm{CD}^{+}{ }^{+}$cells, the expression of HLA-DR on CD3 ${ }^{+}$and $\mathrm{CD} 8^{+}$ T cells, and the expression of CD45RO and CD45RA on CD4 ${ }^{+} \mathrm{T}$ cells in different groups are shown in bar graphs (mean \pm SD). D The percentages of Tregs (CD4 ${ }^{+}$CD25 $5^{+}$CD127 low) in lymphocytes are shown in bar graphs (mean \pm SD). (E) The percentages of CD69 in NK cells are shown in bar graphs (mean $\pm \mathrm{SD}) .{ }^{*} p<0.05,{ }^{* *} p<0.01,{ }^{* * *} p<0.001$

in patients with DLBCL (Fig. 1C). Furthermore, the proportions of Tregs $\left(\mathrm{CD} 4^{+} / \mathrm{CD} 25^{+} / \mathrm{CD} 127^{\text {low }}\right)$ and $\mathrm{CD} 69^{+}$ NK cells were higher in patients with DLBCL compared with those of HCs (Fig. 1D, E).

The IPI score, which is the main prognostic factor for DLBCL, was used to stratify patients into low- to lowmiddle-risk (IPI scores 0-2), high-middle to high-risk (IPI scores 3-5) groups. The absolute counts of $\mathrm{CD}^{+}$, $\mathrm{CD} 4^{+} \mathrm{T}$ cells and those of NK cells were lower in the low-risk (IPI scores 0-2) and high-risk (IPI scores 3-5) groups compared with those of HCs. The numbers of $\mathrm{CD}^{+} \mathrm{T}$ cells were relatively lower only in high-risk patients. However, there were no significant differences between lymphocyte subsets of the two groups (Fig. 2A). The levels of $\mathrm{CD} 28$ expressed by $\mathrm{CD} 4{ }^{+} \mathrm{T}$ cells were lower in low-risk patients (IPI scores 0-2) compared with those of high-risk patients (IPI scores 3-5); and the CD28 levels of both patient groups were lower compared with those of HCs (Fig. 2B). Lower percentages of HLA-DR expressed on $\mathrm{CD}^{+} \mathrm{T}$ cells were only observed in highrisk (IPI scores 3-5) patients (Fig. 2C). CD45RO and CD45RA levels differed among patients compared with those of HCs (Fig. 2D). Furthermore, increased percentages of Tregs were only observed in the high-risk group (Fig. 2E).

The functions of lymphocytes were detected based on IFN- $\gamma$ secretion assay upon PMA/ionomycin stimulation according to our previous studies [16-18]. An exhaustion pattern of $\mathrm{T}$ cells was observed, and patients' $\mathrm{CD} 4^{+}$ and $\mathrm{CD}^{+} \mathrm{T}$ cells showed lower capability of IFN- $\gamma$ production compared with those of HCs, but the levels of IFN- $\gamma$ produced by NK cells were not significantly lower (Fig. 3A). Further analysis revealed that the capability of 

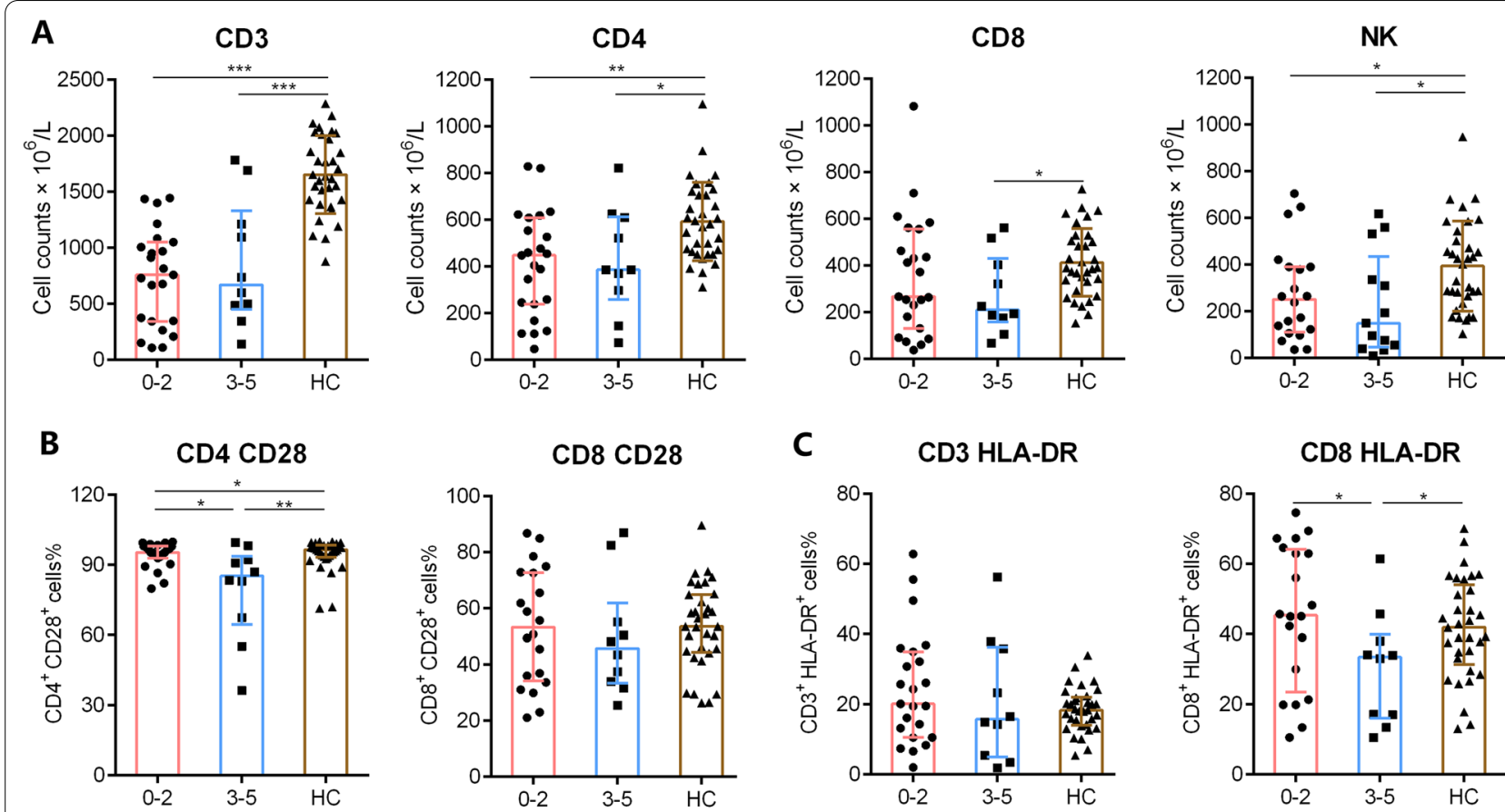

C

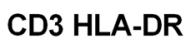

CD8 HLA-DR
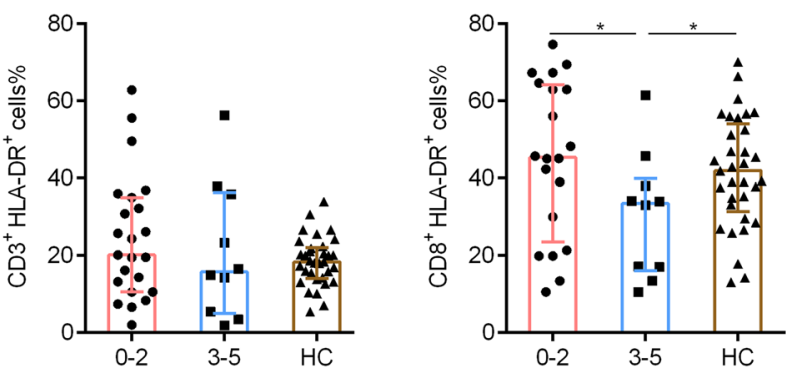

D

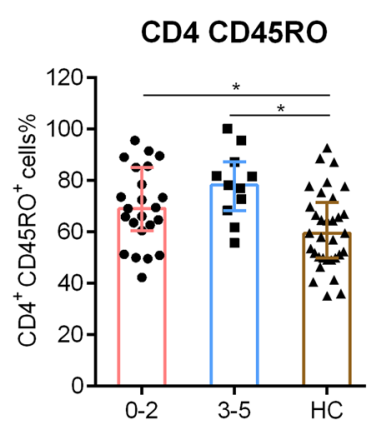

E

Treg
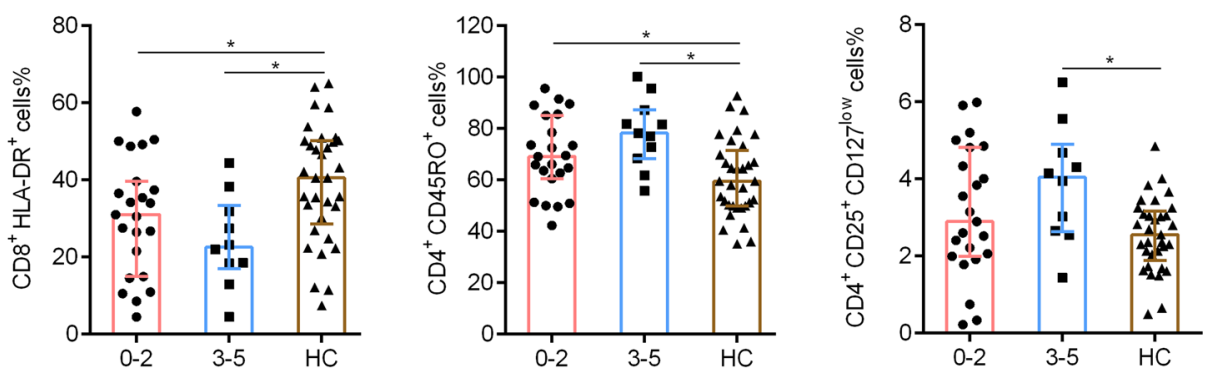

Fig. 2 The subsets and phenotypes of lymphocytes in patients with DLBCL according to IPI scores. Patients with DLBCL were stratified into low- to low-mediate-risk (IPI scores 0-2) and mediate-high- to high-risk (IPI scores 3-5) groups. The absolute counts of CD3 ${ }^{+} 3_{,} C D 4^{+} T, C D 8^{+} T$ cells and NK cells $(\mathbf{A})$, the percentages of $\mathrm{CD} 28^{+}$cells in $\mathrm{CD} 4^{+}$and $\mathrm{CD} 8^{+} \mathrm{T}$ cells $(\mathbf{B})$, the percentages of HLA-DR ${ }^{+}$cells in $\mathrm{CD} 3^{+} \mathrm{T}$ and $\mathrm{CD} 8^{+} \mathrm{T}$ cells (C), the percentages of $C D 45 \mathrm{RO}^{+}$and $\mathrm{CD} 45 \mathrm{RA}^{+}$cells in $\mathrm{CD} 4^{+} \mathrm{T}$ cells $(\mathbf{D})$ and percentages of Tregs in lymphocytes are shown in different groups (mean \pm SD). ${ }^{*} p<0.05,{ }^{* *} p<0.01,{ }^{* * *} p<0.001$

IFN- $\gamma$ production decreased significantly in high- risk (IPI scores 3-5) compared with those of HCs (Fig. 3B).

Eighteen patients who underwent $\geq 6$ cycles' treatment were analyzed to determine the dynamic changes in lymphocyte subsets and functions. The total counts of $\mathrm{CD}^{+}$, $\mathrm{CD} 4^{+}$, and $\mathrm{CD} 8^{+} \mathrm{T}$ cells progressively decreased during treatment, and reaching their lowest values after 4 cycles' R-CHOP treatment (T2). Recovery of lymphocyte counts was detected during T3, although also significantly lower compared with those of HCs. The counts of NK cells significantly decreased at $\mathrm{T} 1$, and recovery was significantly during T3 (Fig. 4A). The percentages of Tregs relative to those of HCs were high at T1, although they decreased during T2 (Fig. 4B).

When we next assessed the dynamics of activation lymphocytes, we found that the levels of CD28 expressed by $\mathrm{CD} 4^{+}$and $\mathrm{CD} 8^{+} \mathrm{T}$ cells were relatively, although those of HLA-DR gradually increased during T1 (Fig. 5A, B). The percentages of naïve CD45RA ${ }^{+}$ $\mathrm{CD}^{+} \mathrm{T}$ cells decreased, whereas those of memory

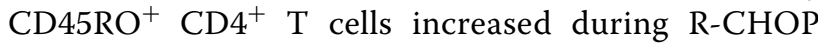
treatment (Fig. 5C). Consistent with $\mathrm{T}$ cell phenotypes, the functions of $\mathrm{CD} 4^{+}$and $\mathrm{CD}^{+}$cells gradually increased during T1, but not that of NK cells (Fig. 6A, $\mathrm{B}, \mathrm{C})$. Continuous clinical monitoring revealed that 12 

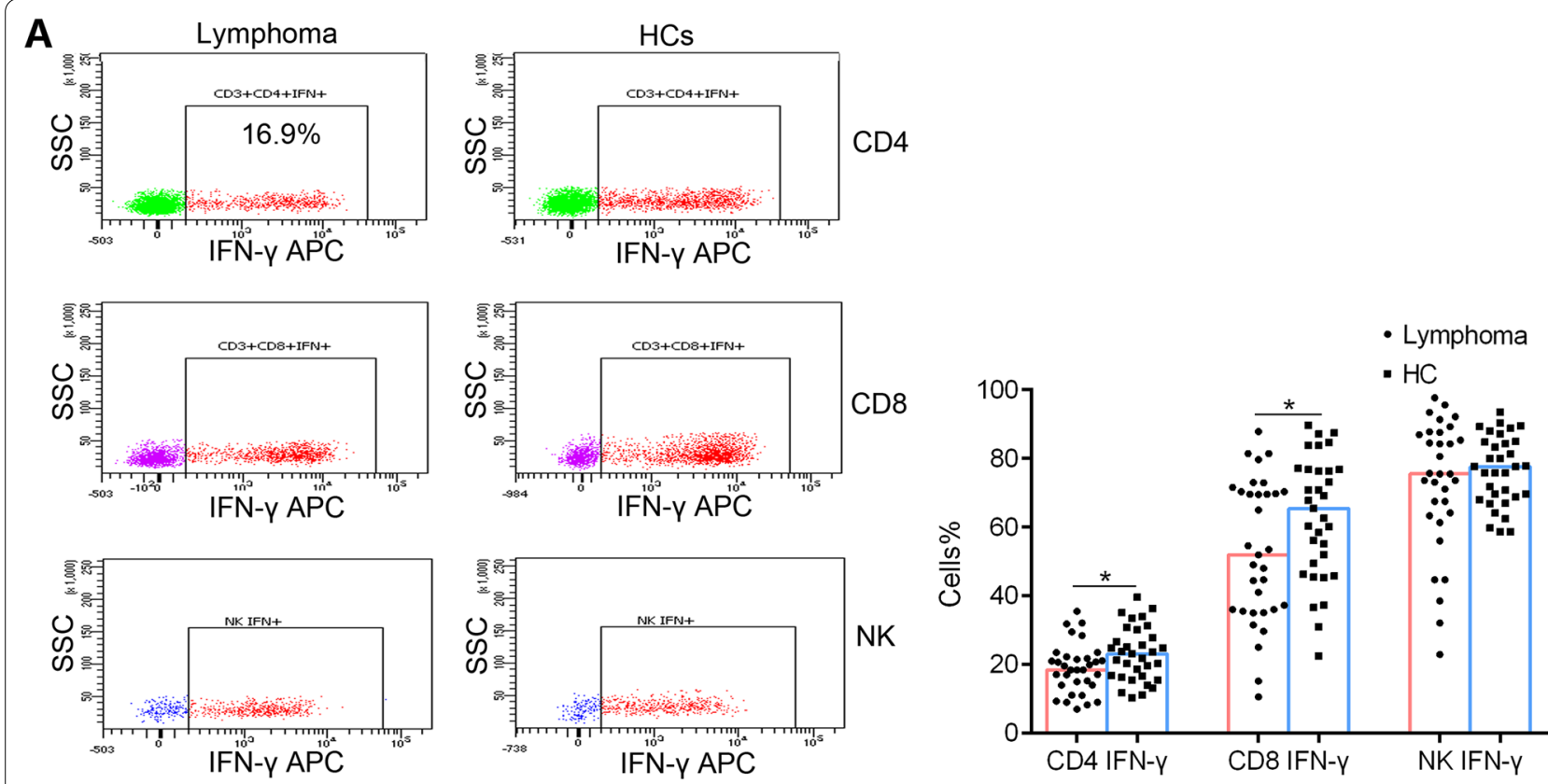

B

CD4 IFN-Y

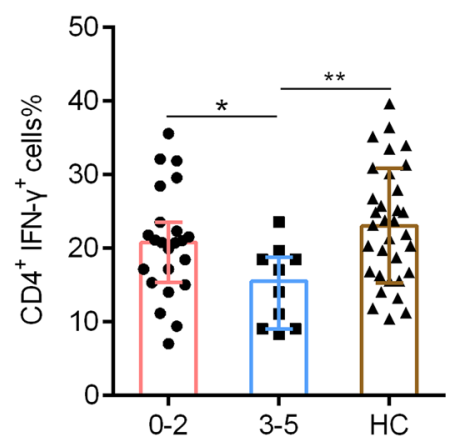

CD8 IFN-Y

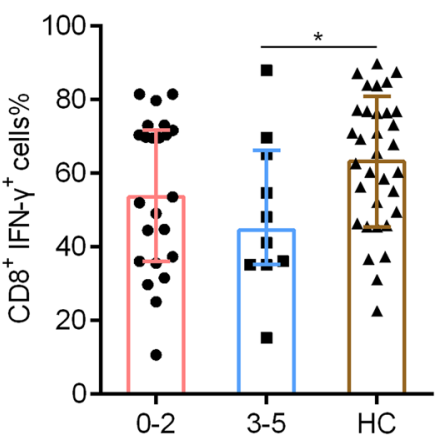

NK IFN-Y

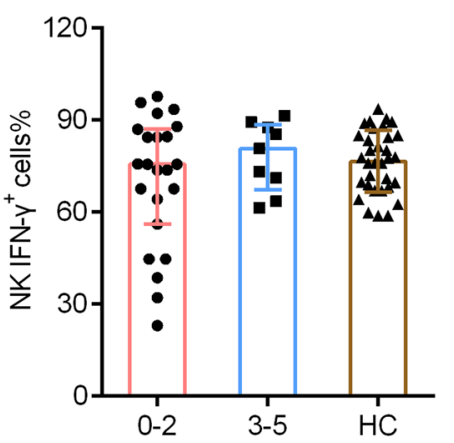

Fig. 3 The IFN- $\gamma$ producing ability of $C D 4^{+} T$ cells, $C D 8^{+} T$ cells, and NK cells. PMA/ionomycin-stimulated lymphocyte function assay was performed in patients with DLBCL and HCS. A Representative FACS dot plots showing the production of IFN- $\gamma$ in $C D 4^{+} T$ cells, CD8 ${ }^{+}$T cells and NK cells. B The percentages of IFN- $\gamma^{+}$cells in CD4 ${ }^{+} \mathrm{T}, \mathrm{CD} 8^{+} \mathrm{T}$ cells and NK cells from patients with lymphoma and $\mathrm{HC}$ s are shown in bar graphs (mean \pm SD). C The percentages of IFN- $\gamma^{+}$cells in $\mathrm{CD}^{+}{ }^{+} \mathrm{T}, \mathrm{CD} 8^{+} \mathrm{T}$ cells and NK cells from patients with low-to low-mediate-risk (IPI scores 0-2) and mediate-high- to high-risk (IPI scores 3-5) are shown in bar graphs (mean \pm SD)

(66.7\%) patients achieved complete remission (CR). The mean absolute numbers of $\mathrm{CD}^{+} \mathrm{T}(937.8 \pm 513.0$ vs. $375.1 \pm 218.5, p=0.022), \mathrm{CD}^{+} \mathrm{T}(417.7 \pm 205.1$ vs. $223.8 \pm 114.9, p=0.041), \mathrm{CD}^{+} \mathrm{T}(327.8 \pm 160.3$ vs. $159.0 \pm 90.8, p=0.017)$ and NK cells $(320.4 \pm 197.4$ vs. $257.5 \pm 197.2, p=0.468)$ were higher in patients who achieved a CR compared with those who did not.

\section{Discussion}

R-CHOP serves as first-line therapy of DLBCL because it significantly lengthens patient survival. Rituximab eradicates malignant cells through complement-dependent cytotoxicity $(\mathrm{CDC})$, and antibody-dependent cell-mediated cytotoxicity (ADCC) and may induce a robust antitumor effect through activation of the immune system [19]. NK cells and T cells mediate this process, which is enhanced through and the activation of $\mathrm{CD} 4^{+} \mathrm{T}$ cells. In the present study, we reveal alterations of lymphocyte subsets and functions in patients with DLBCL. Specifically, we found that lower counts of $\mathrm{CD}^{+}, \mathrm{CD}^{+}, \mathrm{CD} 8^{+}$ $\mathrm{T}$ cells and NK cells and higher percentages of Tregs are present in such patients upon initial diagnosis compared with those of HCs, suggesting depressed immune activity. For example, low $\mathrm{T}$ cell counts serve as an important 
A

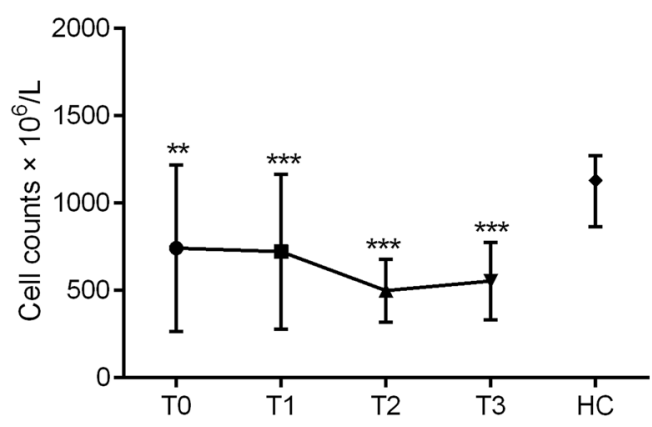

CD8

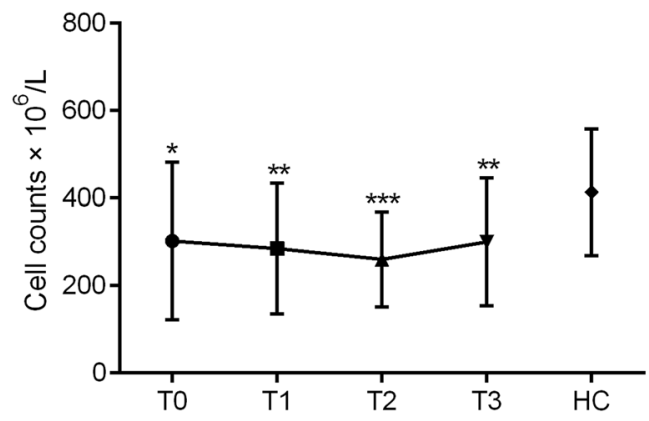

B

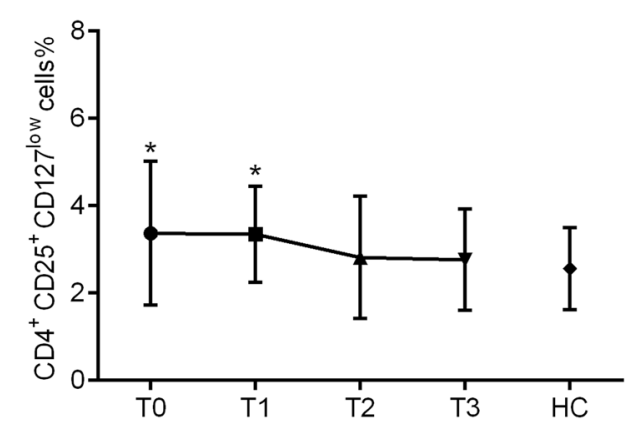

CD4

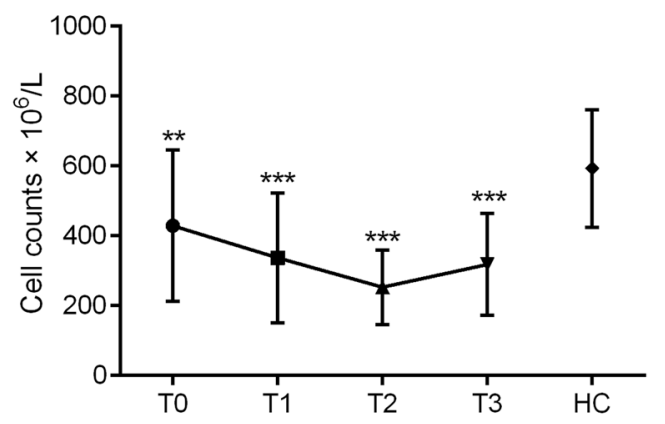

NK

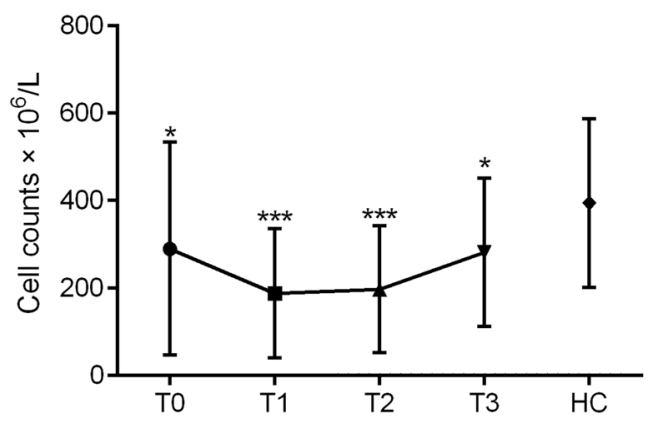

Fig. 4 Dynamic changes of $C D 3^{+} T, C D 4^{+} T, C D 8^{+} T$ cells and NK cells and the percentages of Tregs. The lymphocyte subsets in patients with DLBCL were detected at T0,T1,T2 and T3, respectively. All $p$ values were the results of comparison with $\mathrm{HCs}$. (A) Absolute numbers of $C D 3^{+} \mathrm{T}, \mathrm{CD} 4^{+} \mathrm{T}, \mathrm{CD} 8^{+}$ T cells and NK cells are shown in bar graphs at different time points (mean \pm SD). (B) Percentages of Tregs are shown at different time points

risk factor and an important predictor of progressionfree survival (PFS) and overall survival (OS) $[9,13]$.

We show here that $\mathrm{CD} 4^{+} \mathrm{T}$ cells were generated from naïve cells $\left(\mathrm{CD} 45 \mathrm{RO}^{-} \mathrm{CD} 45 \mathrm{RA}^{+}\right)$to an effector/memory $\left(\mathrm{CD} 45 \mathrm{RO}^{+} \mathrm{CD} 4 \mathrm{RA}^{-}\right)$phenotype in patients with DLBCL, although the functional marker HLA-DR and the levels of costimulatory marker CD28 expressed by $\mathrm{CD}^{+}$and $\mathrm{CD}^{+} \mathrm{T}$ cells were not significantly elevated. NK are major population of cells in peripheral blood that kill tumor cells, and NK cell counts are associated with disease outcomes [20, 21]. Furthermore, a deficiency in
NK cells may correlate with the progression and severity of disease [20]. Therefore, low numbers of lymphocyte subsets are significant markers of immune dysfunction and disease prognosis.

Patients with lower $\mathrm{T}$ cell counts have a poor prognosis $[22,23]$. We therefore analyzed the correlation of lymphocyte subsets with IPI scores. For this purpose, we stratified patients with DLBCL into a low- to low-mediate-risk group (IPI scores 0-2) and mediatehigh- to high-risk groups (IPI scores 3-5). Although the absolute counts of lymphocyte subsets were lower 

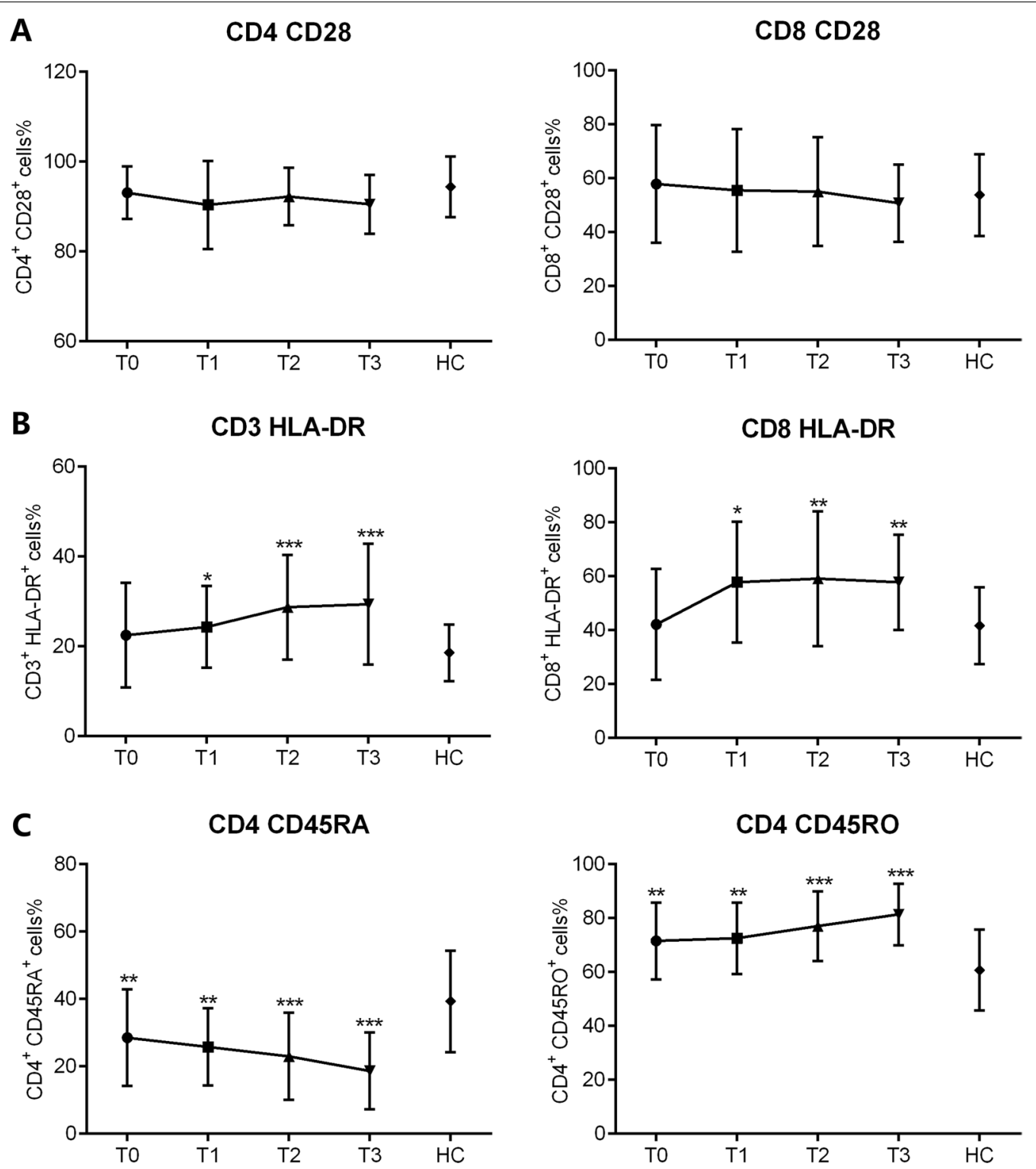

Fig. 5 The dynamic changes of lymphocyte phenotypes. The expression of CD28, HLA-DR, CD45RO and CD45RA were detected at T0, T1, T2 and T3, respectively. The percentages of $C D 28^{+}$cells in $C D 4^{+}$and $C D 8^{+} T$ cells $(\mathbf{A})$, the percentages of $H L A-D R^{+}$cells in $C D 3^{+} T$ and $C D 8^{+} T$ cells $(\mathbf{B})$, and the percentages of $\mathrm{CD} 45 \mathrm{RO}^{+}$and $\mathrm{CD} 45 \mathrm{RA}{ }^{+}$cells in $\mathrm{CD} 4^{+} \mathrm{T}$ cells $(\mathbf{C})$ in patients during $\mathrm{R}-\mathrm{CHOP}$ treatment are shown in bar graphs (mean $\pm \mathrm{SD}$ )

in the mediate-high- to high-risk group compared with those of low to low-mediate-risk group (IPI scores 0-2), but the differences were not significantly. These findings are consistent with those of previous study showing that lymphocyte subset counts are not associated with bone marrow involvement or tumor burden [20]; however, further investigation of larger population are required. Decrease expression of CD28 by $\mathrm{CD} 4^{+} \mathrm{T}$ cells and active cytotoxicity of $\mathrm{CD} 8^{+} \mathrm{T}$ cells was observed in patients with high IPI scores. These results suggest that the decrease in lymphocyte numbers and active phenotypes was a secondary manifestation of DLBCL, independent of the IPI score. This may be explained by the inability of IPI score to identify a poor prognostic group with less than a $50 \%$ chance of survival after the administration of rituximab [24]. Therefore, broader explorations of the host's immune system may identify more informative indicators of the prognosis of patients with lymphoma.

In the present study, we observed decreased IFN- $\gamma$ production by $\mathrm{CD} 4^{+}$and $\mathrm{CD} 8^{+} \mathrm{T}$ cells, revealing an impaired cellular immune response of patients with DLBCL. CD8 ${ }^{+}$ 
A

CD4 IFN-Y

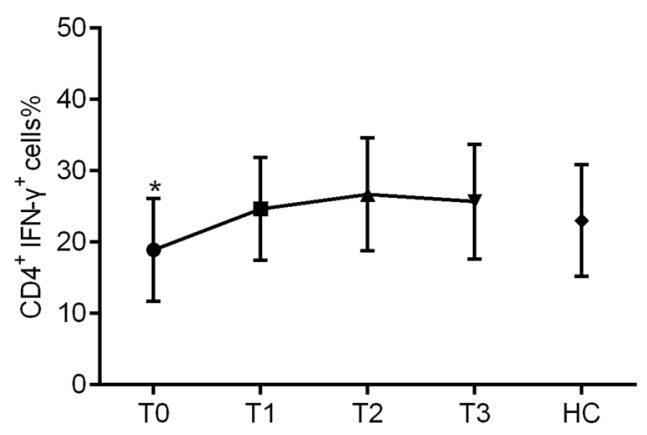

C NKIFN-Y

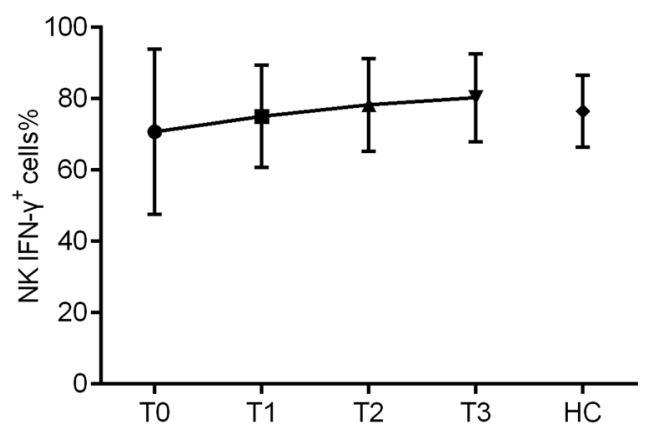

B CD8 IFN-Y

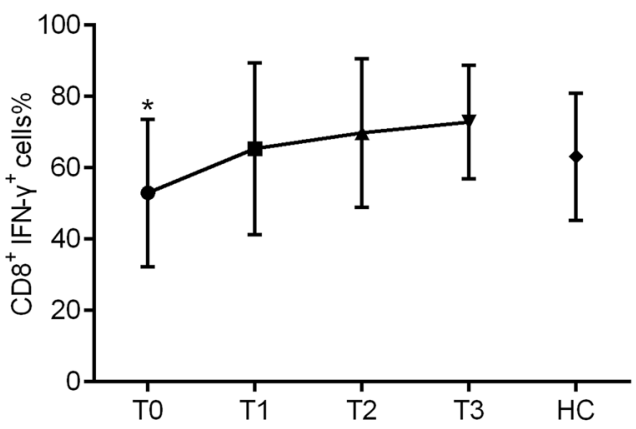

Fig. 6 The dynamic changes of IFN- $\gamma$ producing ability in CD4 ${ }^{+} T$ cells, $C D 8^{+} T$ cells, and NK cells. The secretion capability of IFN- $\gamma^{+}$from CD4 ${ }^{+} T$, $\mathrm{CD} 8^{+} \mathrm{T}$ cells and NK cells were assessed at T0,T1, T2 and T3, respectively. Percentages of IFN- $\gamma^{+}$cells in CD4 ${ }^{+} \mathrm{T}(\mathbf{A}), \mathrm{CD} 8^{+} \mathrm{T}(\mathbf{B})$ and NK $(\mathbf{C})$ cells are shown in bar graphs (mean \pm SD)

$\mathrm{T}$ cells are the major effector cells that mediate antitumor immunity, although antigen-specific $C D 4^{+} \mathrm{T}$ cells contribute to the activation of antigen-presenting dendritic cells and the secretion of cytokines [25]. Therapies that reverse immunosuppression and immune dysfunction may prove to be most effective. Therefore, the combined assessment of the numbers and functions of lymphocytes play a pivotal role in evaluation of the host's immune status as well as for predicting the prognosis of patients with DLBCL who under immunotherapy.

The cytotoxic effects of chemotherapy reduce the numbers of $\mathrm{CD}^{+}, \mathrm{CD}^{+}, \mathrm{CD}^{+}{ }^{+} \mathrm{T}$ cells and NK cells. Here, we found that the earliest recovery of lymphocytes occurred at the end of six cycles of R-CHOP treatment, although the counts of lymphocyte subsets in patients with DLBCL were still lower compared with those of HCs. In contrast, the percentage of Tregs decreased at the end of the second cycle $\mathrm{R}-\mathrm{CHOP}$ treatment. Tregs suppress other immune cells and maintain immune tolerance, and higher percentages of Tregs correlate with shorter survival [15]. The absolute numbers of $\mathrm{T}$ cells and NK cells were higher in patients who achieved a CR compared with those who did not, suggesting that lymphocyte numbers may serve as informative therapeutic markers for predicting the response of patients to $\mathrm{R}-\mathrm{CHOP}$ treatment. These results suggest that the absolute number of lymphocyte subsets is an important therapeutic marker for evaluating patients administered R-CHOP treatment. Furthermore, the percentage of HLA-DR ${ }^{+} \mathrm{T}$ cells gradually increased, but not those of $\mathrm{T}$ cells expressed CD28. Lymphopenia and a dysregulated cytokine milieu are characteristic of DLBCL $[26,27]$, which is consistent with our present findings of $\mathrm{T}$ cell dysfunction. We further found that the $\mathrm{T}$ cells recovered their function at the end of 2 cycles of R-CHOP treatment. NK cells contribute to the innate immune surveillance of $\mathrm{B}$ cell lymphomas, and a deficiency in NK cell is associate with disease outcome [20]. Although impaired NK cell function occurred observed in cancers such as AML [28], it may be a minor effect on the progression of DLBCL. These results reflect generalized depressed immune activity, and the recovery of host immunity correlates with effective treatment. Further studies are required to analyze the correlation of lymphocyte function with the clinical features and OS. 
This study had several limitations. First, lymphocytopenia occurs in NHL and HL, and thus lymphocyte counts and functions of other subsets of lymphomas other than DLBCL must be assessed in future studies. Second, the present results require validation through studies of more patients with lymphomas, particularly those that include comparisons of blood lymphocytes subpopulations with those of TILs. Third, the significant of combining lymphocyte counts, phenotypes and functions for predicting the prognosis of OS and PFS of patients with DLBCL requires further investigations.

\section{Conclusions}

The numbers and functions of lymphocytes, mainly $\mathrm{CD}^{+}$and $\mathrm{CD}^{+} \mathrm{T}$ cells, were significantly decreased in DLBCL. The absolute numbers of lymphocytes were recovered gradually after 6 cycles treatment of R-CHOP, and the function recovered after 2 cycles treatment. These results show that changes in the lymphocyte-mediated immune response of patients with DLBCL occur during $\mathrm{R}-\mathrm{CHOP}$ treatment and support the conclusion that systemic immune evaluation will significantly contribute to the development of innovative treatment to improve clinical prognosis.

\begin{abstract}
Abbreviations
DLBCL: Diffuse large B cell lymphoma; HCs: Healthy controls; IPI: International Prognostic Index; R: Rituximab; CHOP: Cyclophosphamide, doxorubicin, vincristine and prednisone (CHOP); NHL: Non-Hodgkin's lymphoma; Tregs: Regulatory T cells; NK: Natural killer; PFS: Progression-free survival; OS: Overall survival.
\end{abstract}

\section{Supplementary Information}

The online version contains supplementary material available at https://doi. org/10.1186/s12935-021-01978-w.

Additional file 1: Figure S1. The template for analysis of lymphocyte phenotypes by flow cytometry.

\section{Acknowledgements}

Not applicable.

\section{Authors' contributions}

HYH wrote the manuscript. YL and BZ collected the materials of patients. GXT and RROY did the flow cytometry. MH, TW and SJW analyzed the data. FW and DJL helped revise the manuscript. All authors have read and approved the final manuscript.

\section{Funding}

This study was funded by the National Mega Project on Major Infectious Disease Prevention (2017ZX10103005-007).

Availability of data and materials

Not applicable.

\section{Declarations}

Ethics approval and consent to participate

The study was approved by the ethical committee of Tongji hospital, Tongji Medical College, Huazhong University of Science and Technology. Informed written consent was obtained from the patients.

\section{Consent for publication}

Written informed consent for publication of the clinical details was obtained from the patients.

\section{Competing interests}

The authors declare that they have no competing interest.

Received: 30 November 2020 Accepted: 13 May 2021

Published online: 27 May 2021

\section{References}

1. Swerdlow SH, Campo E, Pileri SA, Harris NL, Stein H, Siebert R, Advani R, Ghielmini M, Salles GA, Zelenetz AD, et al. The 2016 revision of the World Health Organization classification of lymphoid neoplasms. Blood. 2016;127(20):2375-90.

2. Liu Y, Barta SK. Diffuse large B-cell lymphoma: 2019 update on diagnosis, risk stratification, and treatment. Am J Hematol. 2019;94(5):604-16.

3. Sehn LH, Gascoyne RD. Diffuse large B-cell lymphoma: optimizing outcome in the context of clinical and biologic heterogeneity. Blood. 2015;125(1):22-32.

4. Molina A. A decade of rituximab: improving survival outcomes in nonHodgkin's lymphoma. Annu Rev Med. 2008;59:237-50.

5. Friedberg JW. Relapsed/refractory diffuse large B-cell lymphoma. Hematology Am Soc Hematol Educ Program. 2011;2011:498-505.

6. Kumar D, Xu ML. Microenvironment Cell Contribution to Lymphoma Immunity. Front Oncol. 2018:8:288.

7. de Charette M, Houot R. Hide or defend, the two strategies of lymphoma immune evasion: potential implications for immunotherapy. Haematologica. 2018;103(8):1256-68.

8. Mocikova H. Prognostic significance of absolute lymphocyte count and lymphocyte subsets in lymphomas. Prague Med Rep. 2010;111(1):5-11.

9. Cox MC, Nofroni I, Ruco L, Amodeo R, Ferrari A, La Verde G, Cardelli P, Montefusco E, Conte E, Monarca B, et al. Low absolute lymphocyte count is a poor prognostic factor in diffuse-large-B-cell-lymphoma. Leuk Lymphoma. 2008;49(9):1745-51.

10. Oki Y, Yamamoto K, Kato H, Kuwatsuka Y, Taji H, Kagami Y, Morishima Y. Low absolute lymphocyte count is a poor prognostic marker in patients with diffuse large B-cell lymphoma and suggests patients'survival benefit from rituximab. Eur J Haematol. 2008;81(6):448-53.

11. Ansell SM, Stenson M, Habermann TM, Jelinek DF, Witzig TE. Cd4+T-cell immune response to large B-cell non-Hodgkin's lymphoma predicts patient outcome. J Clin Oncol. 2001;19(3):720-6.

12. Kusano $Y$, Yokoyama M, Terui $Y$, Nishimura N, Mishima Y, Ueda K, Tsuyama $\mathrm{N}$, Yamauchi $\mathrm{H}$, Takahashi A, Inoue N, et al. Low absolute peripheral blood CD4+ T-cell count predicts poor prognosis in R-CHOP-treated patients with diffuse large B-cell lymphoma. Blood Cancer J. 2017;7(4):e558.

13. Judd J, Dulaimi E, Li T, Millenson MM, Borghaei H, Smith MR, Al-Saleem T. Low level of blood CD4(+) T cells is an independent predictor of inferior progression-free survival in diffuse large B-cell lymphoma. Clin Lymphoma Myeloma Leuk. 2017;17(2):83-8.

14. Muris JJ, Meijer CJ, Cillessen SA, Vos W, Kummer JA, Bladergroen BA, Bogman MJ, MacKenzie MA, Jiwa NM, Siegenbeek van Heukelom LH, et al. Prognostic significance of activated cytotoxic T-lymphocytes in primary nodal diffuse large B-cell lymphomas. Leukemia. 2004;18(3):589-96.

15. Chang C, Wu SY, Kang YW, Lin KP, Chen TY, Medeiros LJ, Chang KC. High levels of regulatory $T$ cells in blood are a poor prognostic factor in patients with diffuse large B-cell lymphoma. Am J Clin Pathol. 2015;144(6):935-44

16. Hou H, Zhou Y, Yu J, Mao L, Bosco MJ, Wang J, Lu Y, Mao L, Wu X, Wang $F$, et al. Establishment of the reference intervals of lymphocyte function in healthy adults based on IFN-gamma secretion assay upon 
phorbol-12-myristate-13-acetate/ionomycin stimulation. Front Immunol. 2018;9:172.

17. Tang G, Yuan X, Luo Y, Lin Q, Chen Z, Xing X, Song H, Wu S, Hou H, Yu J, et al. Establishing immune scoring model based on combination of the number, function, and phenotype of lymphocytes. Aging. 2020;12(10):9328-43.

18. Hou H, Luo Y, Wang F, Yu J, Li D, Sun Z. Evaluation of lymphocyte function by IFN-gamma secretion capability assay in the diagnosis of lymphoma-associated hemophagocytic syndrome. Hum Immunol. 2019;80(12):1006-11.

19. Abes R, Gelize E, Fridman WH, Teillaud JL. Long-lasting antitumor protection by anti-CD20 antibody through cellular immune response. Blood. 2010;116(6):926-34.

20. Plonquet A, Haioun C, Jais JP, Debard AL, Salles G, Bene MC, Feugier P, Rabian C, Casasnovas O, Labalette M, et al. Peripheral blood natural killer cell count is associated with clinical outcome in patients with aalPI 2-3 diffuse large B-cell lymphoma. Ann Oncol. 2007;18(7):1209-15.

21. Moretta A, Marcenaro E, Parolini S, Ferlazzo G, Moretta L. NK cells at the interface between innate and adaptive immunity. Cell Death Differ. 2008:15(2):226-33.

22. Wahlin BE, Sundstrom $C$, Holte $H$, Hagberg $H$, Erlanson M, Nilsson-Ehle $H$, Linden $\mathrm{O}$, Nordstrom M, Ostenstad B, Geisler CH, et al. T cells in tumors and blood predict outcome in follicular lymphoma treated with rituximab. Clin Cancer Res. 2011;17(12):4136-44.

23. Selenko N, Majdic O, Jager U, Sillaber C, Stockl J, Knapp W. Cross-priming of cytotoxic T cells promoted by apoptosis-inducing tumor cell reactive antibodies? J Clin Immunol. 2002;22(3):124-30.
24. Sehn LH, Berry B, Chhanabhai M, Fitzgerald C, Gill K, Hoskins P, Klasa R, Savage KJ, Shenkier T, Sutherland J, et al. The revised International Prognostic Index (R-IPI) is a better predictor of outcome than the standard IPI for patients with diffuse large B-cell lymphoma treated with R-CHOP. Blood. 2007;109(5):1857-61.

25. Protti MP, De Monte L, Di Lullo G. Tumor antigen-specific CD4+T cells in cancer immunity: from antigen identification to tumor prognosis and development of therapeutic strategies. Tissue Antigens. 2014;83(4):237-46

26. Yang Z, Yu W, Wang S, Zhou X, Liu S, Ma S. Peripheral blood lymphocyte subsets of newly diagnosed DLBCL patients and their dynamic changes with rituximab based immunochemotherapy. Leuk Lymphoma. 2019;60(12):2909-16.

27. Charbonneau B, Maurer MJ, Ansell SM, Slager SL, Fredericksen ZS, Ziesmer SC, Macon WR, Habermann TM, Witzig TE, Link BK, et al. Pretreatment circulating serum cytokines associated with follicular and diffuse large B-cel lymphoma: a clinic-based case-control study. Cytokine. 2012;60(3):882-9.

28. Carlsten $\mathrm{M}$, Järås M. Natural killer cells in myeloid malignancies: immune surveillance, NK cell dysfunction, and pharmacological opportunities to bolster the endogenous NK cells. Front Immunol. 2019;10:2357.

\section{Publisher's Note}

Springer Nature remains neutral with regard to jurisdictional claims in published maps and institutional affiliations.
Ready to submit your research? Choose BMC and benefit from:

- fast, convenient online submission

- thorough peer review by experienced researchers in your field

- rapid publication on acceptance

- support for research data, including large and complex data types

- gold Open Access which fosters wider collaboration and increased citations

- maximum visibility for your research: over $100 \mathrm{M}$ website views per year

At BMC, research is always in progress.

Learn more biomedcentral.com/submissions 